\title{
PEMBELAJARAN MENGGUNAKAN MEDIA VISUAL PROYEKSI DALAM KETERAMPILAN MENULIS TEKS FABEL PADA SISWA KELAS VII SMP NEGERI 5 KOTA BENGKULU TAHUN AJARAN 2016/2017
}

\author{
Septiza Haryani, Syukri Hamzah, dan Arono \\ Program Studi Pendidikan Bahasa Indonesia \\ Jurusan Pendidikan Bahasa dan Seni \\ FKIP Universitas Bengkulu \\ septyzha@yahoo.co.id
}

\begin{abstract}
Abstrak
Penelitian ini bertujuan menggambarkan Pembelajaran Menggunakan Media Visual Proyeksi dalam Keterampilan Menulis Teks Fabel Pada Siswa Kelas VII SMP Negeri 5 Kota Bengkulu Tahun Ajaran 2016/2017.Penelitian ini merupakan penelitian metode deskriptif dengan pendekatan kuantitatif.Populasi dalam penelitian ini siswa kelas VII SMP Negeri 5 Kota Bengkulu tahun ajaran 2016/2017 dengan jumlah 240 siswa.Teknik pengumpulan data menggunakan teknik tes.Instrumen pada penelitian adalah dengan menggunakan tes tertulis. Teknik analisis data memberikan penilaian (skor terhadap menulis siswa), penilaian dilakukan oleh dua orang yaitu penilai satu peneliti sendiri (P1) dan penilai kedua (P2) Guru Bahasa Indonesia SMP Negeri 5 Kota Bengkulu, menggunakan skor P1 dan P2, menghitung nilai rata-rata siswa dengan menggunakan rumus. Hasil perhitungan yang dianalisis diperoleh nilai rata-rata sebesar 71,82 nilai tersebut bila dilihat pada kriteria penilaian termasuk dalam kategori baik karena terletak pada interval nilai 70-79. Dengan demikian, kemampuan menulis teks fabel pada siswa kelas VII SMP Negeri 5 Kota Bengkulu termasuk dalam kategori baik. Rincian kemampuan menulis siswa yaitu: 2 siswa termasuk dalam kategori nilai sangat baik, 6 siswa termasuk kategori nilai baik, 17 siswa termasuk dalam kategori nilai cukup, tidak ada siswa termasuk dalam kategori nilai kurang, dan tidak ada siswa dalam kategori nilai sangat kurang.
\end{abstract}

\section{Kata kunci : keterampilan menulis teks fabel}

Abstract
This study aims describe Learning Using Visual Media Projection in FibonacciText Writing
Skills at Grade VII Students of SMP Negeri 5 Bengkulu City Academic Year 2016/2017. This
research is a descriptive method research with quantitative approach. The population in this
study are students of class VII of SMP Negeri 5 Kota Bengkulu academic year 2016/2017
with the number of 240 students. Technique of collecting data using test technique. The
instrument in the study was by using written test. The data analysis technique gives an
appraisal (scores on student writing), the assessment is done by two people, namely the
appraiser of one researcher himself (P1) and the second appraiser (P2) of Indonesian
Language Teachers of SMP Negeri 5 Kota Bengkulu, using score P1 and P2, average students
using the formula. The results of the calculation analyzed obtained an average value of
71.82 value when viewed in the assessment criteria included in either category because it is
located at the interval value of $70-79$. Thus, the ability to write fable text on the seventh
grade students of SMP Negeri 5 Kota Bengkulu included in either category. Details of
students' writing ability are: 2 students included in the category of excellent grades, 6


students included good value category, 17 students included in the category of sufficient value, no students included in the category of less value, and no students in thecategory of very less value.

\section{Keywords: writing skill fable text}

\section{PENDAHULUAN}

Perkembangan ilmu pengetahuan dan teknologi semakin mendorong upayaupaya pembaharuan dalam pemanfaatan hasil-hasil teknologi dalam proses belajar. Para guru dituntut agar mampu menggunakan alat-alat yang dapat disediakan oleh sekolah, dan tidak tertutup kemungkinan bahwa alat-alat tersebut sesuai dengan perkembangan dan tuntunan zaman. Guru sekurangkurangnya dapat menggunakan alat yang murah dan efisien yang meskipun sederhana dan bersahaja tetapi merupakan keharusan dalam upaya mencapai tujuan pengajaran yang diharapkan. Di samping mampu menggunakan alat-alat yang tersedia, guru dituntut untuk dapat mengembangkan keterampilan membuat media pembelajaran yang akan digunakan apabila media tersebut belum tersedia.

Media pembelajaran memainkan peran dalam pencapaian hasil belajar.Saat ini perkembangan teknologi sangat pesat, sehingga komputer bukan lagi barang mewah dan hampir ada di setiap rumah. Adanya fenomena ini telah mendorong penulis untuk memanfaatkan media visual proyeksi ini sebagai alat bantu pembelajaran. Melalui alat bantu ini diharapkan siswa mempunyai minat yang lebih tinggi sehingga prestasi belajar mereka lebih baik.

Banyak media yang bisa digunakan dalam menunjang proses belajar mengajar seperti media visual berupa gambar, media audio seperti rekaman, radio dan sebagainya. Berdasarkan observasi awal yang penulis lakukan terlihat bahwa kurang atau minimnya penggunaan media visial proyeksi di SMP Negeri 5 Kota Bengkulu. Berdasarkan observasi awal penelitian yang akan dilakukan oleh penulis bahwasannya motivasi siswa dalam belajar masih rendah. Hal ini dikarenakan kurangnya sarana penunjang seperti $L C D$ atau INFOKUS yang kurang merata disetiap kelas. Selanjutnya, dengan keterbatasan media tersebut mengakibatkan kurangnya minat siswa dalam proses belajar, sehingga motivasi belajar siswa rendah. Maka dari itu, pemilihan media dalam proses belajar mengajar memiliki banyak jenisnya tinggal menyesuaikan antara tujuan pembelajaran dengan karakteristik media tersebut. Beragam jenis media yang ada tersebut mengalami perkembangan yang pesat terutama dari segi penyajian yang semakin hari semakin inovatif.

Dewasa ini pengembangan media pembelajaran disesuaikan dengan kondisi pengajar dan peserta didik, terutama respon dan menyampaikan pesan pengajar kepada siswa saja akan tetapi media pembelajaran diharapkan mampu menarik minat peserta belajar untuk mampu memahami lebih jauh tentang isi materi yang disampaikan oleh guru atau pengajar. Observasi awal penulis melihat bahwa peserta didik belum begitu mengenal aplikasi yang berbentuk audio maupun visual.Kendala selanjutnya guru tidak terlalu sering menerapkan aplikasi media visual proyeksi yang berbentuk visual. Hal ini tidak signifikan dengan apa yang penulis dapatkan selama diperkuliahan, seperti pemanfaatan media disekolah, RPP,dan silabus. Sarana penunjang dalam meningkat proses belajar, metode dalam kelompok besar, kelompok kecil, bermain peran dan sebagainya. Dengan begitu 
penulis menerapkan media visual proyeksi agar dapat memberikan respon yang lebih baik dalam mengikuti proses belajar mengajar dibandingkan pengajaran tanpa menggunakan media visual proyeksi. Dengan adanya media tersebut maka minat belajar siswa menjadi tinggi dan lebih semangat. Hal inilah yang menjadi landasan penulis untuk meneliti tentang penggunaan media visual proyeksi dalam menulis teks fabel di SMP Negeri 5 Kota Bengkulu.

Penggunaan alat bantu atau media pembelajaran diharapkan dapat mengoptimalkan proses pembelajaran di dalam kelas maupun di luar kelas. Sehingga bisa memotivasi siswa untuk belajar dengan senang yang akhirnya dapat meningkatkan prestasi siswa. Sedangkan secara psikologi, berarti usaha yang dapat menyebabkan seseorang atau kelompok orang tergerak melakukan sesuatu karena ingin mencapai tujuan yang dikehendakinya, atau mendapat kepuasan dengan perbuatannya.Dengan adanya motivasi dari guru dapat membuat siswa semangat dalam melakukan rutinitasrutinitas yang sedang mereka lakukan dan dapat mendorong siswa agar aktif dan menumbuhkan rasa semangat dalam belajar.

Pada penelitian ini media visual proyeksi dipilih sebagai media yang digunakan dalam proses kegiatan belajar mengajar. Selain itu, media visual mudah digunakan dan dimanfaatkan sebagai proses kegiatan belajar-mengajar yang menyenangkan dan tidak membosankan pada saat pembelajaran bahasa Indonesia. Salah satu teks yang digunakan dalam menggunakan media visual proyeksi adalah teks fabel. Teks fabel merupakan cerita yang mengenai kehidupan binatang yang berprilaku layaknya seperti manusia. Cerita fabel tergolong kedalam jenis cerita fiksi yang bukan berasal dari kehidupan yang nyata atau disebut juga dengan cerita
fiktif.Cerita fabel disebut juga dengan cerita moral, hal tersebut dikarenakan pesan yang terdapat didalam cerita fabel sangat erat kaitannya dengan moral kehidupan.

Kurikulum 2013 yang mulai diterapkan dibeberapa sekolah yang ada di Provinsi Bengkulu mengajarkan tentang berbagai macam teks, salah satunya, yaitu teks cerita fabel. Menurut Priyatni (2014:37) dalam Kurikulum 2013, bahasa Indonesia tidak hanya difungsikan sebagai alat komunikasi, tetapi juga sebagai sarana berpikir. Bahasa adalah sarana untuk mengekspresikan gagasan dan sebuah gagasan yang utuh biasanya direalisasikan dalam bentuk teks.Teks dimaknai sebagai ujaran atau tulisan yang bermakna, yang memuat gagasan yang utuh.Dengan asumsi tersebut, fungsi pembelajaran bahasa adalah mengembangkan kemampuan memahami dan menciptakan teks karena komunikasi terjadi dalam teks atau pada tataran teks.Pembelajaran berbasis teks inilah yang digunakan sebagai dasar pengembangan kompetensi dasar mata pelajaran Bahasa Indonesia ranah pengetahuan dan keterampilan dalam Kurikulum 2013.

Tujuan dalam proses pembelajaran merupakan komponen pertama yang harus ditetapkan dalam proses pembelajaran, sekaligus berfungsi sebagai indikator keberhasilan dalam proses pembelajaran. Metode pembelajaran yang digunakan dalam proses pembelajaran dipilih atas dasar bahan tujuan yang telah ditetapkan sebelumnya. Salah satu metode yang dapat menarik adalah pembelajaran dengan menggunakan media pembelajaran.

\section{METODE}

Metode yang digunakan dalam penelitian ini adalah metodedeskriptif dengan pendekatan kuantitatif, yaitu secara objektif apa adanya sesuai dengan 
fakta yang ada mengenai pembelajaran menggunakan media visual proyeksi dalam keterampilan menulis teks fabel kelas VII SMP Negeri 5 Kota Bengkulu Tahun Ajaran 2016/2017. Design penelitian menggunakan Pretest-Posttest design karena pada desain ini terdapat pretes, sebelum diberi perlakuan. Dengan demikian hasil perlakuan dapat diketahui lebih akurat, karena dapat membandingkan dengan keadaan sebelum diberi perlakuan (Sugiyono. 2014: 74-75).

Penelitian ini dilakukan di SMP Negeri 5 Kota Bengkulu pada siswa kelas VII semester genap tahun 2016/2017. Waktu penelitian ini dilaksanakan pada bulan November 2017.

Adapun populasi penelitian ini adalah siswa kelas VII SMP Negeri 5 Kota Bengkulu tahun ajaran 2016/2017. Random sampling mengambil anggota sampel dari populasi dilakukan secara acak tanpa memperhatikan strata yang ada dalam populasi itu. Dengan demikian peneliti sampel dalam penelitian ini yaitu berjumlah 25 siswa.

Teknik ini bertujuan untuk memperoleh data mengenai keterampilan menulis siswa ke dalam bentuk teks cerita fabel. Pemberian tes sesuai dengan materi kurikulum SMP kelas VII semester genap.

Instrumen pada penelitian ini adalah dengan menggunakan tes tertulis.Tes yang digunakan memberikan jawaban apakah menulis teks cerita fabel menggunakan media visual proyeksi dan yang tidak menggunakan media proyeksi.

Setelah data terkumpul, untuk mengetahui gambaran tersebut diambil langkah-langkah sebagai berikut:

1. Memberikan penilaian (skor terhadap hasil menulis siswa).

2. Penilaian dilakukan oleh dua orang yaitu penilai satu (P1) peneliti sendiri dan penilai dua (P2) guru Bahasa Indonesia di SMP Negeri 5 Kota Bengkulu.
3. Menggabungkan skor dari P1 dan P2.

4. Menghitung nilai rata-rata siswa dengan rumus:

$\mathrm{M}=\frac{\sum X}{N}$

\section{HASIL PENELITIAN DANPEMBAHASAN Hasil Penelitian}

Adapun media pembelajaran adalah segala sesuatu yang dapat menyampaikan dan menyalurkan pesan dari sumber secara terencana sehingga tercipta lingkungan belajar yang kondusif dimana penerimannya dapat melakukan proses belajar secara efesien dan efektif. Gagne (1970), mengatakan bahwa media adalah berbagai jenis komponen atau sumber belajar dalam lingkungan pembelajar yang dapat merangsang pembelajar untuk belajar. Briggs (1970), mengatakan media adalah segala wahana atau alat fisik yang dapat menyajikan pesan serta merangsang pembelajar untuk belajar. Maka secara umum media adalah "alat bantu" yang dapat digunakan dalam proses pembelajaran (Sanaky, 2009:3).

Hasil penelitian kemampuan menulis teks fabel siswa kelas VII SMP Negeri 5 Kota Bengkulu tahun ajaran 2016/2017 terdiri atas lima aspek yaitu: 1$)$ isi, 2) struktur, 3) kosakata, 4) gaya bahasa, 5) mekanik. Data masing-masing aspek akan disajikan berikut ini.

Hasil perhitungan yang dianalisis diperoleh nilai rata-rata sebesar 71,82 . Nilai tersebut bila dilihat pada kriteria penilaian termasuk dalam kategori baik karena terletak pada interval nilai 70-79. Dengan demikian, kemampuan menulis teks fabel siswa kelas VII SMP Negeri 5 Kota Bengkulu termasuk dalam kategori baik. Rincian kemampuan menulis siswa yaitu: 2 siswa termasuk dalam kategori nilai sangat baik, 6 siswa termasuk dalam kategori nilai baik, 17 siswa termasuk dalam kategori nilai cukup, tidak ada siswa termasuk dalam kategori nilai kurang, dan 
tidak ada siswa dalam kategori nilai sangat kurang.

Kemampuan menulis teks fabel kelas VII SMP Negeri 5 Kota Bengkulu dengan frekuensi tertinggi berada pada kategori cukup dengan 17 siswa.Frekuensi tertinggi kedua berada pada kategori baik dengan 6 siswa.Frekuensi tertinggi ketiga berada pada kategori sangat baik dengan 2 siswa.frekuensi terendah berada pada kategori kategori sangat kurang dengan 0 siswa.

Setelah dilaksanakan kegiatan belajar menulis teks fabel di SMPNegeri 5 Kota Bengkulu maka diperoleh hasil belajar kemampuan menulis siswa berada pada kategori cukup bisa dilihat pada (tabel 4) hasil penelitian. Hasil perhitungan dari nilai maksimal 25 tersebut diperoleh nilai ratarata sebesar 71,82 yang berarti berada lebih besar dari modus yaitu 70 , sedangkan nilai median 71hampir mendekati nilai rata-rata. Standar deviasi diperoleh4,0 ini berarti bahwa nilai yang diperoleh siswa terpencar, karena semakin tinggi nilai standar deviasi maka semakin tersebar pula nilai yang diperoleh oleh masingmasing siswa. Dengan melihat hal ini berarti nilai yang diperoleh siswa cenderung mendekati nilai rata-rata, dan median. Nilai 71,82 dan 71 berada pada rentang $62-74 \%$ pada kategori cukup. Jadi dapat dinyatakan bahwa hasil belajar kemampuan menulis teks fabel pada siswa kelas VIISMP Negeri 5 Kota Bengkulu berada pada kategori cukup.

Dari analisis data yang telah dilakukan dan gambaran hasil yang diperoleh bahwa siswa kelas VII SMP Negeri 5 Kota Bengkulu kemampuan menulis teks fabel menggunakan media visual proyeksi berada pada kategori cukup.tetapi secara keseluruhan tergambar bahwa dengan menggunkan media pembelajaran memberikan peran posistif terhadap pemahaman siswa tentang materi teks fabel ini, sesuai dengan hakikatnya bahwa teks fabel adalah sebuah teks yang menceritakan tentang kehidupan binatang yang berprilaku seperti manusia.

Dengan demikian kita dapat mengetahui kemampuan siswa dalam mengungkapkan gagasan terhadap objek yang diamati berada pada kategori cukup. Penilaian terhadap hasil belajar kemampuan menulis siswa ini meliputi aspek isi yang dijabarkan, penyusunan kalimat sehingga menjadi paragraph yang utuh sesuai dengan struktur teks, kosa kata, pilihan kata yang cocok dan tepat dalam menerangkan objek yang diamati, serta penggunaan bahasa dan mekanik yang tepat.

\section{Pembahasan}

Penilaian Terhadap Aspek Isi Hasil Belajar Keterampilan Menulis Teks Fabel pada Siswa Kelas VII SMP Negeri 5 Kota Bengkulu

Berdasarkan data yang diperoleh maka penulis memaparkan penilaian dari aspek isi pada tabel di atas terlihat bahwa hasil perhitungan dari nilai maksimal 25 tersebut diperoleh nilai rata-rata sebesar 16,82 yang berarti nilai rata-rata siswa lebih kecil dari modus yaitu 16,5, sedangkan nilai median 16,5 hampir mendekati nilai modus yaitu 16,5 . Standar deviasi dari penilaian terhadap apek isi yaitu 17 ini berarti bahwa sebaran nilai yang diperoleh siswa berada jauh nilai rata-rata, karena semakin tinggi nilai standar deviasi maka semakin tersebar pula nilai yang diperoleh oleh masingmasing siswa.Dengan melihat ini berarti nilai yang diperoleh siswa cenderung mendekati nilai modus dan median. Nilai 16,82 berada pada rentang $16-20$ dengan kategori baik. Jadi dapat disimpulkan bahwa penilaian hasil belajar menulis teks deskripsi pada aspek isi berada pada kategori baik. 
Selain itu, dari hasil analisis data yang telah dilakukan pada aspek isi, kebanyakan siswa sudah dapat membuat teks fabel secara baik, sesuai dengan kategori penilian dalam aspek isi, seperti informasi yang disajikan lengkap, jelas, padat, dan sesuai dengan topik yang ditetapkan. Hanya saja ada beberapa siswa yang kesulitan dalam menuangkan informasi secara lengkap, jelas, dan padat.

\section{Penilaian terhadap Aspek Struktur Teks Hasil Belajar Keterampilan Menulis Teks Fabel Pada Siswa Kelas VII SMP Negeri 5 Kota Bengkulu}

Tahap menulis berikutnya ialah tahap menulis, yaitu kegiatan pengembangan kerangka menjadi bentuk draf tulisan yang sesuai dengan struktur penulisan teks deskripsi yakni Identifikasi/defini umum, deskripsi bagian (Harsiati,2016:141).

Berdasarkan data yang diperoleh maka penulis memaparkan penilaian dari aspek struktur pada tabel di atas terlihat bahwa hasil perhitungan dari nilai maksimal 25 tersebut diperoleh nilai ratarata sebesar 17,5 yang berarti nilai ratarata siswa sama dengan nilai modus yaitu 17,5 sedangkan nilai median 17,5 dari nilai modus. Standar deviasi dari penilaian terhadap apek isi yaitu 0,75 ini berarti bahwa sebaran nilai yang diperoleh siswa berada jauh dari nilai rata-rata siswa, karena semakin tinggi nilai standar deviasi maka semakin tersebar pula nilai yang diperoleh oleh masing-masing siswa. Dengan melihat ini berarti nilai yang diperoleh siswa cenderung mendekati nilai median. Nilai 17,5 berada pada rentang 1620 dengan kategori baik. Struktur teks membentuk struktur berpikir sehingga disetiap penggunaan jenis teks tertentu, siswa akan memiliki kemampuan berpikir sesuai dengan struktur teks yang dikuasainya.
Jadi, dapat disimpulkan bahwa penilaian hasil belajar menulis teks deskripsi pada aspek organisasi berada pada kategori baik.

\section{Penilaian Terhadap Aspek Kosa Kata Hasil Belajar Keterampilan Menulis Teks Fabel pada Siswa Kelas VII SMPNegeri 5 Kota Bengkulu.}

Dalam penilaian aspek kosa kata, hal yang dinilai dari hasil tulisan siswa kelas VII SMPNegeri 5 Kota Bengkulu ialah komponen bahasa yang memuat semua informasi tentang pemakaian kata.Menurut KBBI (2016) kosa kata adalah perbendaharaan kata atau banyaknya kata-kata yang dimiliki suatu bahasa. Berdasarkan data yang diperoleh maka penulis memaparkan penilaian dari aspek diksi pada tabel di atas terlihat bahwa hasil perhitungan dari nilai maksimal 15 tersebut diperoleh nilai ratarata sebesar 15,38 yang berarti nilai ratarata siswa lebih besar dari modus yaitu 15,5 , sedangkan nilai median 15,5sama besar dari nilai modus. Standar deviasi dari penilaian terhadap aspek kosa kata yaitu 1,26 ini berarti bahwa sebaran nilai yang diperoleh siswa mendekati nilai rata-rata, karena semakin tinggi nilai standar deviasi maka semakin tersebar pula nilai yang diperoleh oleh masing-masing siswa. Dengan melihat ini berarti nilai yang diperoleh siswa cenderung mendekati nilai median. Nilai 15,38 berada pada rentang 11-15 dengan kategori cukup. Meskipun begitu masih terdapat beberapa orang siswa yang memiliki kemampuan yang kurang memadai dalam aspek kosa kata. Pengguasaan kosa kata siswa masih terbatas karena kurangnya pengetahuan siswa sehingga siswa kesulitan dalam memilih kata yang tepat untuk mewakili ide atau gagasan yang disampaikan dalam tulisan.

Jadi dapat disimpulkan bahwa penilaian hasil belajar menulis teks fabel 
pada aspek kosa kata berada pada kategori cukup

\section{Penilaian Terhadap Aspek Gaya Bahasa Hasil Belajar Keterampilan Menulis Teks Fabel pada Siswa Kelas VII SMPNegeri5 Kota Bengkulu.}

Wibowo (2013: 3) menyimpulkan bahwa bahasa adalah sistem symbol buny yang bermakna dan berartikulasi yang bersifat arbitrer dan kovensional, yang dipakai sebagai alat komunikasi oleh sekelompok manusia untuk melahirkan perasaan dan pikiran.

Berdasarkan data yang diperoleh maka penulis memaparkan penilaian dari aspek penggunaan bahasa pada tabel di atas terlihat bahwa hasil perhitungan dari nilai maksimal 15 tersebut diperoleh nilai rata-rata sebesar 14,98 yang berarti nilai rata-rata siswa lebih besar dari modus dan median yaitu 15, Standar deviasi dari penilaian terhadap aspek gaya bahasa yaitu 0,97 ini berarti bahwa sebaran nilai yang diperoleh siswa mendekati nilai ratarata, karena semakin tinggi nilai standar deviasi maka nilai yang diperoleh oleh masing-masing siswa mendekati nilai ratarata. Dengan melihat ini berarti nilai yang diperoleh siswa jauh dari nilai modus median. Nilai 14,98 berada pada rentang 11-15 dengan kategori cukup. Siswa sudah dapat tepat dalam menggunakan gaya bahasa yang baik untuk digunakan atau tidak digunakan untuk mewakili ide atau gagasan yang disampaikan, sebab gaya bahasa yang dipilih memiliki peranan penting untuk menyampaikan informasi dalam tulisan.

Jadi dapat disimpulkan bahwa penilaian hasil belajar menulis teks fabel pada aspek penggunaan bahasa berada pada kategori cukup.Penggunaan kalimat yang tepat dan efektif, pemelihan kalimat perintah dan konjungsi yang tepat.
Penilaian Terhadap Aspek Mekanik Hasil Belajar Keterampilan Menulis Teks Fabel pada Siswa Kelas VII SMPNegeri 5 Kota Bengkulu.

Berdasarkan data yang diperoleh maka penulis memaparkan penilaian dari aspek mekanikpada tabel di atas terlihat bahwa hasil perhitungan dari nilai maksimal 10 tersebut diperoleh nilai ratarata sebesar 7,41yang berarti nilai ratarata siswa lebih besar dari modus yaitu 7 dan nilai median 7, Standar deviasi dari penilaian terhadap apek isi yaitu 0,80 ini berarti bahwa sebaran nilai yang diperoleh siswa mendekati nilai rata-rata, karena semakin tinggi nilai standar deviasi maka semakin tersebar pula nilai yang diperoleh oleh masing-masing siswa. Dengan melihat ini berarti nilai yang diperoleh siswa jauh dari nilai modus median. Nilai 7,41 berada pada rentang 6-10 dengan kategori kurang. Jadi dapat disimpulkan bahwa penilaian hasil belajar menulis teks fabel pada aspek mekanik berada pada kategori kurang.

\section{PENUTUP}

\section{Simpulan}

Proses pembelajaran yang menggunakan media visual proyeksi power point dapat membantu meningkatkan motivasi siswa dalam pembelajaran. Dalam penelitian ini peneliti menggunakan pendekatan saintifik yang terdiri dari beberapa langkah-langkah sebagai berikut: (1) pendahuluan. (2) inti ( mengamati, menanya, menalar, mencoba, mengkomunikasikan), (3) penutup.

Keterampilan Menulis Teks Fabel Siswa Kelas VII SMP Negeri 5 Kota Bengkulu. Presentase yang dihasilkan siswa dalam menulis cerita fabel menggunakan media visual proyeksi power point ratarata mencapai angka $71,28 \%$ yang termasuk dalam kategori baik. 


\section{Saran}

1. Sebagai seorang guru seharusnya menggunakan media pada saat proses pembelajaran agar pembelajarana menjadi lebih efektif dan efisien.

2. Bagi siswa hendaknya lebih diberikan latihan menulis guna meningkatkan keterampilan menulis.

\section{DAFTAR PUSTAKA}

Endah, Tri Priyatni. 2014. Desain Pembelajaran Bahasa Indonesia dalam Kurikulum 2013.
Harsiati, Titik dkk. 2016. Bahasa Indonesia Edisi Revisi. Jakarta: Kementerian dan Kebudayaan.

Sanaky, A. 2009.Media Pembelajaran. Yogyakarta: Safira Insania Press.

Sugiyono. 2014. Metode Penelitian Kuantitatif, Kualitatif, dan R\&D. Bandung: ALFABETA.

Tarigan, Henry Guntur. 2013. Menulis: Sebagai Suatu Keterampilan Berbahasa. Bandung: CV Angkasa. 